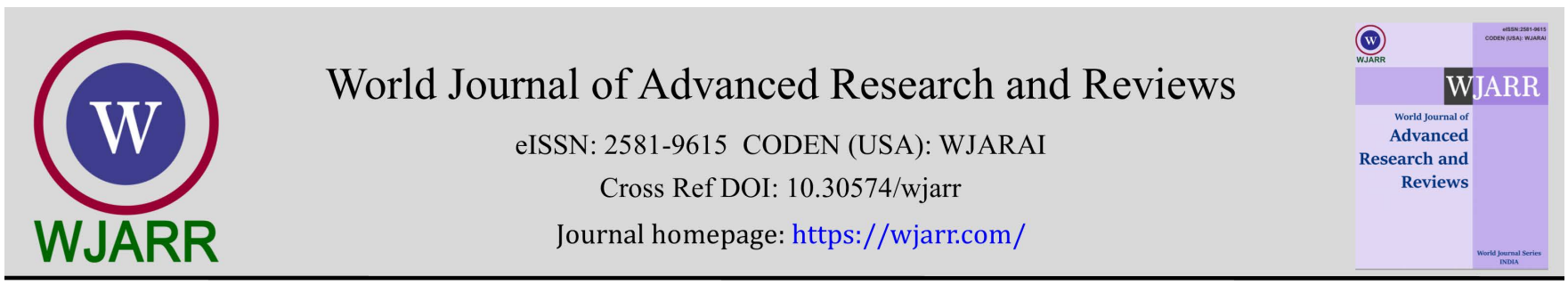

(REVIEW ARTICLE)

\title{
Antiproliferative activity of marine brown algae-derived compounds: A review
}

Luane Oliveira Araújo ${ }^{1}$, Jessyca Karoline de Oliveira Silva ${ }^{2}$, Beatriz Alves de Aguiar ${ }^{2}$, Julliene Larissa dos Santos Bezerra ${ }^{2}$, Aline de Queiroz Rodrigues ${ }^{2}$ and Fernanda Paulini 2,*

${ }^{1}$ Department of Pharmacy, Faculty of Health, University of Brasília, Brasília, Brazil.

2 Department of Physiological Sciences, Institute of Biological Sciences, University of Brasília, Brasília, Brazil.

World Journal of Advanced Research and Reviews, 2021, 11(01), 060-072

Publication history: Received on 28 May 2021; revised on 05 July 2021; accepted on 09 July 2021

Article DOI: https://doi.org/10.30574/wjarr.2021.11.1.0306

\begin{abstract}
Marine environment exploration has increased in the search for new compounds that may be attractive to the industrial field, especially for the development of drugs. Brown marine algae are part of this environment and, because of their production of secondary metabolites, they have become a possible source of bioactive compounds that have important biological actions such as anticoagulant, antioxidant and antiproliferative. However, there are still obstacles to complete knowledge about their structures and activities. This review provides key information about the isolation, composition, and structure and antiproliferative activity in vitro and in vivo of compounds derived from different brown algae.
\end{abstract}

Keywords: Marine Natural Products; Seaweeds; Antitumoral compounds; Marine biodiversity

\section{Introduction}

The marine environment has a wide variety of species, such as invertebrate animals, macroalgae, fungi and bacteria [1]. Due to their biodiversity, the oceans are able to produce an abundance of chemical structures with a high potential for the discovery of new compounds with pharmacological properties [2] and, among them, macroalgae or algae are the most promising marine organisms [3].

Algae are photosynthetic, multicellular and talophyte organisms, classified according to the specific combination of their photosynthetic pigments, which may be green (Chlorophyceae), consisting mainly of chlorophyll A and B; brown (Phaeophyceae), having $\beta$-carotene and xanthophylls; or red (Rhodophyta), containing chlorophyll phycoerythrin [4]. They are considered exceptional marine organisms, because in addition to producing primary metabolites essential for their survival, they also produce secondary metabolites, which help them to interact with the environment under different conditions of salinity, oxygen concentration, pollution, exposure to ultraviolet radiation and herbivory [5]. Some of the metabolites produced by algae, such as terpenoids, alkaloids, polyphenols, steroids, pigments and polysaccharides, have already had their antiviral(6), anti-adhesive [7], anticoagulant, antioxidant, anti- inflammatory $[8,9]$ and cytotoxic / antiproliferative [10] activities studied both in vitro and in vivo [11,12].

Thus, after long years of being used in industrial products and as a complementary source in food due to their high nutritional value $[13,14]$, algae have started to gain relevance in the pharmaceutical and medicinal field. The isolation or discovery of new molecules from these organisms can play a very important role as an alternative therapeutic agent in various diseases, mainly against cancer [15]. According to Alves et al., 2018 [11], among all the treatments used against cancer (chemotherapy, radiotherapy, hormonal treatment, immunotherapy, adjunct therapy and surgery), chemotherapy continues to play an extremely important role. However, its effectiveness can be compromised by drug resistance and intolerable adverse effects.

\footnotetext{
${ }^{*}$ Corresponding author: Fernanda Paulini

Department of Physiological Sciences, Institute of Biological Sciences, University of Brasília, Brasília, Brazil.
} 
In this context, research aiming to improve cancer treatments and increase the life expectancy of people affected by cancer are extremely necessary and important, especially with regard to the discovery of new drugs. One of the lines of research that stands out is the discovery of bioactive compounds from brown algae (Phaeophyta) [16]. Studies indicate that this marine class has great potential as antineoplastic agents or as models for their creation [3]. Thus, due to the remarkable potential of brown seaweed, the goal of this review is to present an overview of the isolation, composition, structure and antiproliferative activity of these organisms, addressing their main secondary metabolites, in an attempt to shed light on future research into these compounds.

\section{Main secondary bioactive metabolites with antiproliferative activity pinpointed in brown algae}

\section{$2.1 \quad$ Fucans and fucoidans}

The name of the sulfated polysaccharides found in brown algae has always been related to their chemical composition [17]. In 1913, Kylin named the first isolated polysaccharide from seaweed "fucoidin" [18]. Forty years later, McNeely changed the nomenclature "fucoidin" to fucoidan and, to date, terms like fucan, fucosan or sulfated fucan are used as synonyms by many authors [8]. However, due to the existence of homo- and heterofucan classifications, the International Union of Pure and Applied Chemistry (IUPAC) recommends that the term sulfated fucan should be used to define a molecule that contains less than $10 \%$ of other monosaccharides $[19,20]$. Thus, given that there is no consensus in the literature related to which nomenclature is correct, this review will follow the IUPAC recommendations and use the term fucan for homofucans that contain less than $10 \%$ of other monosaccharides, and the term fucoidans to refer to heterofucans with more than $10 \%$ of other monosaccharides.

\subsubsection{Chemical composition}

Fucans are sulfated polysaccharides that have a simpler composition, with sulfated $\alpha$-L-fucose as the main component $[20,21]$. In contrast, fucoidans have a more complex and heterogeneous composition. In addition to fucose and sulfate, they also contain other monosaccharides such as mannose, galactose, glucose, xylose and uronic acids, even acetyl and protein groups $[8,19]$.

Sulphated polysaccharides undergo seasonal variations, meaning that their composition varies according to the seasons [22]. The maturity and location of algae are also directly related to the production of these metabolites [23]. Moreover, each alga produces a type of sulfated polysaccharide, some of which can even produce more than one type [24,25]. These factors explain why such diverse compositions are found and the difficulty in identifying a specific metabolite.

\subsubsection{Extraction methods of fucans and fucoidans}

There are several methods used to extract fucoidans or fucans. Among these methodologies, the most important are aqueous extraction [26], acid extraction [27], cell wall extraction [28] and extraction by the action of proteolytic enzymes [29]. However, despite the increase in the number of studies related to the biological activity of sulfated polysaccharides extracted from brown seaweed, there is still no standard established in the literature on what is the best methodology for extracting these compounds [30]. Furthermore, depending on the process employed, substances with different compositions, structures and molecular weights may occasionally be obtained [30]. An example of this is the position and amount of sulfate groups that fucoidans have [24].

Some studies have shown that the degree of sulfation of fucoidans can influence the biological activities of these substances $[8,19,31,32]$. It has been reported that the distribution of negative charges of sulfate groups may be responsible for recognizing biological targets, such as proteins involved in blood coagulation (antithrombin and heparin II cofactor) or cell proliferation (growth factor receptors) [33]. The extraction of fucans / fucoidans from brown algae is briefly described below, according to the species.

\subsubsection{Undaria pinnatifida}

To obtain the fucoidan from this alga, a combination of trypsin-enzyme hydrolysis and alcohol precipitation is used [34]. According to Cho et al., 2010 [32], to get three fractions of fucoidan with different molecular weights, first the samples must be ground, sieved and stored at $-20^{\circ} \mathrm{C}$. After this process, the dried samples are rehydrated, and the extract is mixed with calcium chloride $\left(\mathrm{CaCl}_{2}\right)$ and centrifuged. Then, ethanol is added to the supernatant, followed by filtration. According to Nardella et al., 1996 [35], the filtered compound must be hydrolyzed to obtain a low-molecular-weight fucoidan. The last stage of the extraction consists of fractioning the compound, using a Millipore Ultrafiltration System with 30 and $5 \mathrm{kDa}$ molecular weight cutting membranes $\left(0.1 \mathrm{~m}^{2}\right.$, Millipore, USA), producing three fractions of fucoidan, $\mathrm{F}_{>30 \mathrm{~K}}(\mathrm{Mw}>30 \mathrm{kDa}), \mathrm{F}_{5-30 \mathrm{~K}}(30 \mathrm{kDa}<\mathrm{Mw}<5 \mathrm{kDa})$ е $\mathrm{F}_{<5 \mathrm{~K}}\left(\mathrm{Mw}_{\mathrm{w}}<5 \mathrm{kDa}\right)$. 
In the study reported by Yang et al., 2008 [36], the fucoidan extraction starts with the ethanol treatment of the ground seaweed, after been washed with acetone, centrifuged and dried. Two extractions with distilled water are made in the dry biomass and then the samples are centrifuged to mix the supernatant with $\mathrm{CaCl}_{2}$. After centrifugation, fucoidan is obtained through filtration and washing with ethanol plus acetone.

\subsubsection{Cladosiphon okamuranus}

Teruya et al., 2007 [27] reported the extraction of the fucoidan from these algae with the homogenization of the sample using hydrochloric acid ( $\mathrm{HCl})$ under agitation to obtain the extract. This extract was centrifuged, filtered and dried under vacuum, so that the fucoidan could be dissolved in a solution containing calcium chloride $\left(\mathrm{CaCl}_{2}\right)$ and be filtered again. The resulting filtrate was dialyzed, deionized and lyophilized.

In another study, nanoparticles containing fucoidan were obtained by suspending the algae in a solution containing citric acid, then neutralized and centrifuged. The supernatant was filtered, concentrated by ultrafiltration and then dried [37]. As demonstrated by Haneji et al., 2005 [38], at the end of the process, the fucoidan was dissolved in phosphatesaline buffer (PBS). In addition to these processes, it is possible to obtain the fucoidan from this species of algae through commercial organizations, such as the NPO Organization Fucoidan Laboratory and FCC Horiuchi \& Co.

\subsubsection{Fucus vesiculosus}

The fucoidans of this algae are available from the company Sigma-Aldrich (St. Louis, MO, U.S.A.), which uses a method based on the isolation method proposed by Black et al., 1952 [39]. Briefly, the washes and the centrifugate are evaporated by drying and the dark extract obtained is redissolved in water. The solution is treated with alcohol, then the precipitates are washed with alcohol or ether and dried until they form a powder. For later use, after being obtained, fucoidan can be dissolved in phosphate buffered saline [10].

\subsubsection{Dictyota cervicornis, Dictyota menstrualis, Dictyopteris delicatula, Dictyota mertensii, Spatoglossum schröederi and Sargassum filipendula}

Costa et al., 2010 [40] performed the extraction of sulfated polysaccharides from these algae using a combinatorial methodology of proteolysis and acetone precipitation. Briefly, the algae were stored, dried and then ground and incubated with acetone to eliminate lipids and pigments. The obtained powder was suspended in volumes of $0.25 \mathrm{M}$ $\mathrm{NaCl}$, the $\mathrm{pH}$ adjusted to 8.0 with $\mathrm{NaOH}$; for proteolytic digestion, maxatase was used. After incubation with shaking for $24 \mathrm{~h}$ at $60{ }^{\circ} \mathrm{C}$, the mixture was filtered and precipitated with acetone. The precipitate formed was collected by centrifugation, dried under vacuum, resuspended in distilled water and reserved for further analysis.

\subsubsection{Cystoseira sedoides, Cystoseira compressa, Cystoseira crinita and Sargassum linearifolium}

A fine powder of these algae is formed after crushing, which must be stored in filter paper bags to be sealed and macerated with water at room temperature. The mixture must then be centrifuged, and the supernatant filtered; only then can the macerate be lyophilized, allowing an aqueous crude extract to be formed for subsequent studies [26].

\subsubsection{Sargassum horneri, Costaria costata and Ecklonia cava}

The fucoidans in these algae are isolated using the modified aqueous extraction method and ion exchange chromatography $[41,42]$. Initially, the fresh or deep-frozen biomass of the algae is treated with ethanol, acetone and chloroform. When the leaves of the algae are dry and powdered, they are extracted twice with $0.1 \mathrm{M} \mathrm{HCl}$. The extracts are combined, centrifuged, dialyzed and concentrated, and the polysaccharides are fractionated in ion exchange chromatography, where a solution of polysaccharides is eluted in a linear gradient of 0 to $2 \mathrm{M}$ of Nacl in a Macro-prep Column DEAE (Bio- Rad, USA). Thus, the resulting fractions can be forwarded to subsequent studies [25].

\subsubsection{Ascophyllum nodosum}

The fucans of these algae can be obtained by acid extraction with $\mathrm{HCl}$, and then they can be filtered and lyophilized [43]. Haroun-Bouhedja et al., 2000 [33] performed acid extraction with the method used by Colliec et al., 1994 [44]: after a series of filtrations with glass microfiber filters, the acid extract was stirred with a cutting membrane and lyophilized. For fractionation in low molecular weight fucans, the acid extract needs to pass through an anion exchange chromatography column, resulting in three fractions with different sulfate percentages. 


\subsubsection{Fucan and fucoidan chemical structures}

The first brown alga to have the average structure of its fucoidan made known was Fucus vesiculosus, with the studies by Conchie et al., 1950 [45], Percival et al., 1950 [46] and O'Neill, 1954 [47], which showed a structure composed mainly of $(1 \rightarrow 2)$ fucopyranose residues with 4 - $O$-sulfated. This structure remained valid for 40 years; however, in 1993 , Patankar et al., 1993 [48] carried out the review of this structure, using acid extraction and more modern chromatography techniques, such as gas chromatography coupled to electron ionization mass spectrometry (CG-EMIE), and arrived at another structural model, suggesting that the central region of the fucoidan was primarily a $\alpha$-(1 $\rightarrow 3)$ linked fucose polymer with sulfate groups substituted at the C-4 position in some of the fucose residues. In addition, fucose was also attached to this polymer to form branched points, one for every 2-3 fucose residues within the chain [48]. Currently, Fucus vesiculosus fucoidan is commercially available (Sigma-Aldrich, St. Louis, MO, USA).

The other algae have reports on their structures, but there is no consensus, since the structural models are dependent on the compositions. Scientific attempts such as comparing the structures of sulfated polysaccharides found in marine invertebrates, which are simpler, with those found in algae, have already been used [49]. However, the variations between the different algae and, sometimes, between different parts of the plant, and, mainly, the different extraction methods, have led to unique structures, which are difficult to replicate [50]. Some of the structures already described and identified by other authors from fucoidans and fucans are shown in Table 1.

Table 1 Chemical structures identified for fucan and fucoidan from brown algae

\begin{tabular}{|c|c|c|c|}
\hline Specie & Compound & Structure & References \\
\hline Fucus evanescens & Fucoidan & $\begin{array}{l}\text { Linear skeleton of alternating } \alpha \text {-L-fucopyranose-2-sulfate } \\
\text { residues: } \rightarrow 3)-\alpha \text {-L-Fucp }(2 S O 3-)-(1 \rightarrow 4)-\alpha \text {-L-Fucp }(2 S O 3-)-(1 \rightarrow\end{array}$ & [8] \\
\hline $\begin{array}{l}\text { Undaria } \\
\text { pinnatifida }\end{array}$ & Fucoidan & $\begin{array}{l}\text { Alternating structure of fucose-galactose linked together by } \\
\text { means of 1,3 glycosidic bonds with sulfation at positions } C 2 \text { and } \\
\text { C4 }\end{array}$ & [51] \\
\hline $\begin{array}{l}\text { Bifurcaria } \\
\text { bifurcata }\end{array}$ & Fucan & Linked fucose residues $(1 \rightarrow 2)$ and $(1 \rightarrow 3)$ with sulfation in C-4 & [52] \\
\hline $\begin{array}{l}\text { Ascophyllum } \\
\text { nodosum }\end{array}$ & Fucoidan & {$[\rightarrow 3)-\alpha-1-F u c(2 S O 3-)-(1 \rightarrow 4)-\alpha-1-F u c(2,3$ diSO3-)-(1]n } & [53] \\
\hline $\begin{array}{l}\text { Sargassum } \\
\text { horneri }\end{array}$ & Fucoidan & $\begin{array}{l}\text { Linear chain of } \alpha \text {-L-fucopyranose residues linked to }(1,3) \text { or } \\
(1,4) \text { with sulfate groups at positions } 2\end{array}$ & [25] \\
\hline $\begin{array}{l}\text { Sargassum } \\
\text { stenophyllum }\end{array}$ & Fucoidan & $\begin{array}{l}\text { Type I: }(1 \rightarrow 6)-\beta \text {-D-galactose and / or }(1 \rightarrow 2) \text { - } \beta \text {-D- mannose } \\
\text { with branch chains formed by }(1 \rightarrow 3) \text { and } / \text { or }(1 \rightarrow 4)-\alpha \text {-L- } \\
\text { fucose, }(1 \rightarrow 4) \text { - } \alpha \text {-D- glucuronic acid. } \\
\text { Type II: }(1 \rightarrow 4) \text { alpha-D-glucuronic acid, terminal } \beta \text {-D-xylose } \\
\text { and sometimes }(1 \rightarrow 4) \text {-alpha-D-glucose }\end{array}$ & [54] \\
\hline $\begin{array}{l}\text { Cladosiphon } \\
\text { okamuranus }\end{array}$ & Fucoidan & - [( $\rightarrow$ 3Fuc-4(+/- OSO3-) $\alpha-1-) 5 \rightarrow 3$ [GlcA $\alpha-1 \rightarrow 2]$ Fuc- $\alpha-1-]$ n- & [55] \\
\hline
\end{tabular}

\subsection{Fucoxanthin}

Some species of brown algae produce the carotenoid pigment called fucoxanthin, which also has identified antiproliferative activity [4].

\subsubsection{Chemical composition}

The carotenoids are a group of natural pigments, with more than 600 members [56], which include two main subclasses: carotenes, which are non-polar hydrocarbons, and xanthophylls, which present themselves as polar compounds with substituent groups such as oxygen, hydroxyls, keto groups and epoxy [57]. A well-known example of xanthophylls is fucoxanthin, isolated for the first time in 1914 from the brown seaweed Fucus, Dictyota and Laminaria [58]. This carotenoid contributes more than $10 \%$ of the total carotenoids in nature, particularly in the marine ecosystem [59].

\subsubsection{Isolation of fucoxanthin}


There are only few reports describing the extraction of fucoxanthin. Hosokawa et al., 2004 [60] reported its isolation from Undaria pinnatifida, which consists of soaking the fresh alga in two volumes (v/w) of methanol for two days, repeating this procedure twice; then, the methanol solution was filtered and evaporated to obtain the methanol extracts. Water and ethyl acetate were added to the extracts, and the ethyl acetate layer was obtained with a separatory funnel. Then, the orange-colored fucoxanthin fraction was separated from the ethyl acetate-soluble fraction by means of preparative silica gel thin layer chromatography carried out with chloroform: methanol: water (65:25:4, v/v/v). A complementary study by the same group reported that the fucoxanthin was purified by low-pressure liquid chromatography with methanol/water $(17: 3 \mathrm{v} / \mathrm{v})$, which means a purity of more than $98 \%$ of fucoxanthin [60].

\subsubsection{Fucoxanthin chemical structure}

Fucoxanthin has the structure $3^{\prime}$-acetoxy-5,6-epoxy-3,5'-dihydroxy-6 $6^{\prime} 7^{\prime}$-didehydro-5,6,7,8,5', $6^{\prime}$-hexahidro- $\beta \beta$ caroten-8-on (Figure 1), which is a unique carotenoid structure that includes an alenic bond and an epoxide [61,62]. Its exceptional structure contributes to the action of different pharmacological activities, such as antioxidant [63], antidiabetic [64], anti-obesity [65], anti-inflammatory [66], neuroprotective [67] and anti-tumor [68,69].

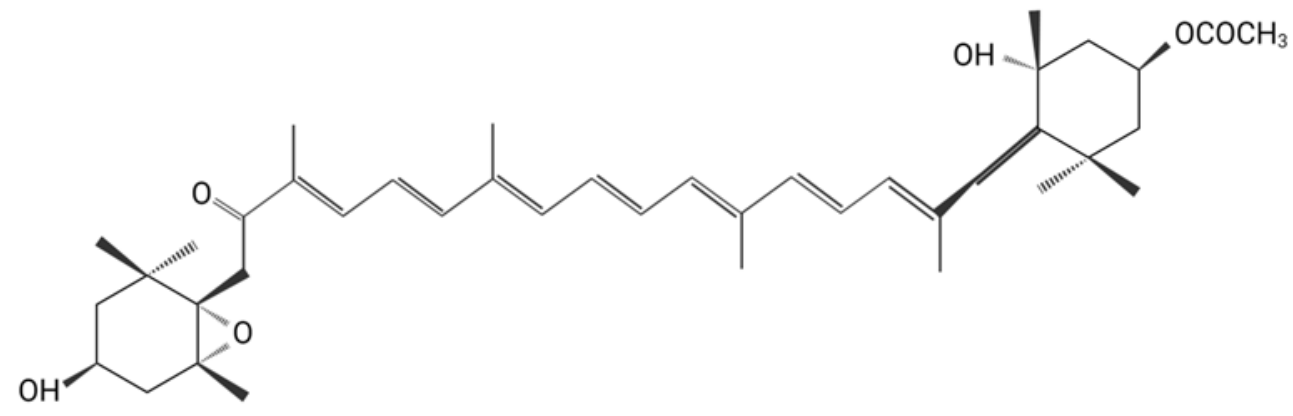

Figure 1 Chemical structure of fucoxanthin.

\section{The bioactivity of brown algae-derived secondary metabolites}

\subsection{Antiproliferative activity in vitro}

Fucus vesiculosus, Undaria pinnatifida and Cladosiphon okamuranus are the brown algae that most show positive results related to antiproliferative effects [70]. Studies carried out using these species noted that the components of $F$. vesiculosus inhibited the number of viable cells of the human colon adenocarcinoma (HT-29, HCT-116) and Burkitt's lymphoma (HS-Sultan) lines through apoptosis [71,72]. In colorectal adenocarcinoma cells (HCT-15), Lewis lung carcinoma (LLC), melanoma (B16) and MCF-7 breast tumor, the fucoidan extracted from the same species inhibited cell proliferation in a dose-dependent manner [10,38,73]. In HS-Sultan cells, the fucoidan from the species Fucus vesiculosus decreased the proliferation of the cancer cell through the activation of caspase- 3 and negative regulation of signalregulated extracellular kinases (ERK) [72]. In another study, it was demonstrated that in human umbilical vein endothelial cells (HUVEC), fucoidan has an antitumor activity, because it suppressed tumor growth, due to its antiangiogenic activity [74]. In the leukemic cell lines HL-60, NB4 and THP-1, fucoidan had a strong apoptotic effect [75].

By means of Undaria pinnatifida, lung cancer cell lineage (A549) underwent antiproliferative action with the tested fucoidan [76]. Meanwhile, hepatocellular carcinoma cells (SMMC-7721) were induced to apoptosis through the mitochondrial pathway mediated by reactive oxygen species (ROS) [34]. In cells of the prostate cancer lineage (PC-3), fucoidan promoted cell death through apoptosis signaling pathways [77]. In gastric adenocarcinoma (AGS) cells, crude and supersulfated fucoidans inhibited their growth, depending on the dose used [32], which also happened with the fibroblast cell line (CCL39) [33].

Using fucoxanthin, the cell lines of human colorectal adenocarcinoma (Caco-2 and DLD-1) and human colon adenocarcinoma (HT-29) had their viability affected and suffered apoptosis after the use of this compound together with the use of triglitazane, which is a ligand for the peroxisome proliferator-activated receptor (PPAR) [75]. Yang et al., 2008 [36] reported that in a lung cancer cell lineage (A549), the antiproliferative effect of fucoidans derived from 
the $U$. pinnatifida species improved when the molecular weight of the compound was reduced, using depolymerization by hydrolysis.

Fucoidans extracted from the species Cladosiphon okamuranus exhibited antiproliferative activity in leukemic cancer lines, inhibiting the growth of cells by apoptosis [38]. In line U937, a human lymphoma cell lineage, the antiproliferative effect occurred through the induction of apoptosis due to activation of the caspase pathways 3 and 7 [27]. In breast cancer MCF-7 cells, cell growth was inhibited via a caspase 8-dependent pathway [78], depending on the dose and / or time of exposure to fucoidan, which was also reported by Fukahori et al., 2008 [79], when working with 15 cancer cell lines, which included hepatocellular, gallbladder, human ovarian cancer, renal cell carcinoma, neuroblastoma, and hepatoblastoma. The results demonstrated the reduction of cell proliferation in 13 cell lines in a dose-dependent or time-dependent manner to exposure to fucoidan.

As explained above, it is possible to test the effects of metabolites extracted from brown algae in a variety of cells. The results indicate that antiproliferative responses depend on the dose used, and most of them occur through means that interfere with apoptotic pathways. Table 2 shows some species of brown algae and their metabolites tested in different cell lines, found in the literature.

Table 2 Marine compounds isolated from brown algae with antiproliferative activity in vitro

\begin{tabular}{|l|l|l|c|}
\hline \multicolumn{1}{|c|}{ Algae } & \multicolumn{1}{|c|}{ Compound } & \multicolumn{1}{|c|}{ Tested cells } & References \\
\hline Ascophyllum nodosum & Fucoidan & CCL39 & {$[33]$} \\
\hline Bifurcaria bifurcata & Methanolic extract & NSCLC-N6 & {$[80]$} \\
\hline $\begin{array}{l}\text { Clasdosiphon novae- } \\
\text { caledoniae }\end{array}$ & Fucoidan & $\begin{array}{l}\text { MCF7, MDA-MB-231, HeLa } \\
\text { and HT1080 }\end{array}$ & {$[81]$} \\
\hline $\begin{array}{l}\text { Cystoseira compressa } \\
\text { and Cystoseira sedoides }\end{array}$ & Aqueous extract & HCT15 and MCF7 & {$[26]$} \\
\hline $\begin{array}{l}\text { Cystoseira crinita } \\
\text { Dictyopteris delicatula }\end{array}$ & Fucan & $\begin{array}{l}\text { MCF-7,HepG2, MIA and PaCa- } \\
2\end{array}$ & {$[82]$} \\
\hline Dictyopteris undulata & Extract & HeLa & {$[24]$} \\
\hline $\begin{array}{l}\text { Dictyota cervicornis and } \\
\text { Dictyota menstrualis }\end{array}$ & $\begin{array}{l}\text { Sulfated } \\
\text { polysaccharide }\end{array}$ & HW480 & {$[83]$} \\
\hline Egregria menziessi & $\begin{array}{l}\text { Hexane } \\
\text { methanolic extract }\end{array}$ & C6 and MIO-M1 & {$[84]$} \\
\hline Fucus evanescens & Fucoidan & Mt-4 & {$[85]$} \\
\hline S. Filipendula & Fucoidan & HeLa, PC3 and HepG2 & {$[29]$} \\
\hline Sargassum linearifolium & Extract & $\begin{array}{l}\text { MCF-7, HepG2, MIA and PaCa- } \\
2\end{array}$ & {$[82]$} \\
\hline Sargassum mcclure & Fucoidan & DLD-1 & {$[86]$} \\
\hline Sargassum sp & Fucoidan & LLC, B16 and BSLT & {$[38 ; 87]$} \\
\hline Sargassum stenophyllum & Fucoidan & B16F10 & {$[28]$} \\
\hline
\end{tabular}

\subsection{Antriproliferative activity in vivo}

There are fewer, but significant, pre- and clinical studies that demonstrate the potential antitumor and / or adjuvant activity of these compounds $[11,19,88,89]$, which are presented according to bioactive. 
World Journal of Advanced Research and Reviews, 2021, 11(01), 060-072

\subsubsection{Fucoidans}

\subsubsection{Fucus vesiculosus}

The study reported by Koyanagi et al., 2003 [79] demonstrated that the degree of sulfation of the fucoidan molecule is important for its antiangiogenic and antitumor activities. In that study, Lewis lung carcinoma cells (LLC) and melanoma cells (B16) were inoculated into mice. Three to five days after inoculation, a single daily dose of Fucus vesiculosus Natural Fucoidan (NF) or Oversulfated Fucoidan (OSF) (5 mg / kg each) was administered intravenously for 21 days. In the evaluation, the authors observed that although the two groups (NF and OSF) showed a decrease in the growth of tumor cells, the OSF group had a more potent effect. In addition, the photographs used to assess the antiangiogenic effect showed that the blood vessels in the mice treated with OSF were practically the same as the control group, treated with phosphate buffered saline (PBS) (not tumor cells). To confirm the means by which these fucoidans were able to inhibit tumor growth, the authors performed an in vitro test with the same cells and observed that the concentration of $100 \mathrm{mg}$ / mL was unable to achieve a cytotoxic effect. Thus, Koyanagi et al., 2003 [79], concluded that the two fucoidans suppress tumor growth through antiangiogenic action, instead of by a direct cytotoxic effect on tumor cells.

Another study performed by Ale et al., 2011 [90] demonstrated that the antitumor effect of fucoidans, derived from the species Fucus vesiculosus and Sargassum sp., is related to a modulation of the immune system, mainly by the increase of NK (Natural Killer) cells. To carry out this evaluation, the authors injected samples of fucoidan intraperitoneally in mice, for four consecutive days. After this period, the quantification of the activity of NK cells could be performed from the chromium-51 (51Cr) release test with the spleen cells of these mice. The results showed that there was an increase in the activity of NK cells at an effector / target ratio of 100: 1 in mice treated with the fucoidans of both species compared to the negative control (saline), leading the authors to conclude that the antitumor activity promoted by fucoidan was based on the increased activity of NK cells.

Another relevant study carried out recently used the serum of mice treated with fucoidan from Fucus vesiculosus (200 or $400 \mathrm{mg} / \mathrm{kg} \cdot$ body weight per day) in the incubation with MCF-7 cells, to investigate its antitumor action [91]. The results showed that the serum with fucoidan effectively inhibited the proliferation of cancer cells, inducing apoptosis. In addition, the compound suppressed the migration of tumor cells by modulating the expression of E-cadherin and MMP-9, proteins that are important for the epithelial-mesenchymal transition (step that helps metastasis) [91].

\subsubsection{Undaria pinnatifida}

Maruyama et al., 2006 [92] studied mice that were fed with a diet containing 1\% of Mekabu's fucoidan (sporophile from Undaria pinnatifida) $(0.034 \pm 0.003 \mathrm{~g} /$ mouse / day). After 10 days of this diet, A20 lymphoma cells were subcutaneously inoculated. Subsequently, the mice were fed using the diet again for 40 days. The authors observed that cell growth was significantly inhibited in these mice (65.4\%). However, tumor growth was not inhibited in mice that were fed with the diet, only 40 days after cell inoculation. After carrying out other experiments that verified the immunological activity of the compound, using transgenic mice with anti-OVA TCR (Do-11 $\pm 10 \pm$ Tg), the authors concluded that the antitumor action of fucoidan is mediated by responses of Th1 cells and Natural Killer cells, rather than by a direct cytotoxic effect.

A non-randomized clinical study conducted at the Royal Hobart Hospital (Hobart, Australia) evaluated the coadministration of fucoidan, derived from Undaria pinnatifida, in the pharmacokinetics of two hormonal therapies commonly used in patients with breast cancer [93]. A $500 \mathrm{mg}$ capsule containing extract of Undaria pinnatifida Maritech (Marinova Pty Ltd, Hobart, Australia) was administered in the morning and evening, after meals, in combination with standard hormonal drugs, letrozole and tamoxifen. The authors reported that the results demonstrated that fucoidan was well tolerated and did not influence the plasma concentrations of standard drugs. Therefore, there was no toxicity or increased adverse effects.

\subsubsection{Cladosiphon okamuranus}

The potential use of the fucoidan obtained from this species in the treatment of osteosarcoma has been reported with two different approaches: native fucoidan and fucoidan nanoparticle (fucoidan encapsulated in a liposomal structure). After inoculation of LM8 osteosarcoma tumor cells in C3H mice, the animals were treated with oral fucoidan of 100 mg / kg / day of nanoparticles of fucoidan or native fucoidan. The mice in the control group were treated with water only (vehicle). The results showed that there was a significant inhibition of tumor growth and spontaneous metastases in the lung of LM8 tumor xenotransplants. The volume and weight of the tumor were reduced in the group of fucoidan nanoparticles compared to the group of mice that received native fucoidan. However, the pulmonary metastasis score decreased in the native fucoidan compared to that observed in the fucoidan nanoparticle [37]. 
The studies by Azuma et al., 2012 [94] also used fucoidan derived from Cladosiphon okamuranus, administered orally (5 mg / kg / day), but with a different approach. The authors evaluated the effects of fucoidans of different molecular weights - low molecular weight (6.5-40 kDa), intermediate molecular weight (110-138 kDa), high molecular weight $(300-330 \mathrm{kDa})$ - in mice with colon tumor 26 (C26). The results revealed that these fucoidans exhibited antitumor action by significantly decreasing the number of mitotic cells in vitro. The authors attributed the mechanism of stimulation of the intestinal immune system, for example, to the increase in Natural Killer cells. In addition, they concluded that differences in the molecular weight of fucoidan can affect the activity of NK cells in vitro.

A clinical trial conducted with the objective of evaluating the action of fucoidan of the species Cladosiphon okamuranus in reducing the adverse effects caused by the chemotherapeutic agents used in patients with advanced or recurrent colorectal cancer demonstrated that the dose of $150 \mathrm{~mL} /$ day of liquid containing $4.05 \mathrm{~g}$ of fucoidan during 6 months of treatment suppressed the occurrence of fatigue and prolonged the duration of chemotherapy treatment by suppressing the toxicity of the drugs [95]. Therefore, fucoidans derived from the brown algae Cladosiphon okamuranus are one of the most promising compounds as adjuvants in the treatment against cancer.

\subsubsection{Fucoxanthin}

This bioactive, responsible for the pigment of brown algae, is also a compound with important anti-tumor activities $[16,68,96]$. A study carried out to verify its inhibitory action on $\mathrm{N}$-ethyl- $\mathrm{N}^{\prime}$-nitro-N-nitrosoguanidine-induced duodenal carcinogenesis revealed that mice treated with fucoxanthin (oral administration in drinking water treated with $0.005 \%$ fucoxanthin in dimethylsulfoxide (DMSO)) for 12 weeks, had a significant reduction in the average number of tumors per mouse and in the percentage of mice with tumor compared to the control group [97]. The authors pointed out the inhibition of the activity of ornithine decarboxylase (ODC) - an enzyme whose activity is induced in response to stimuli of cell growth and which is highly expressed in diseases such as inflammation and cancer - as being the possible mechanism of action of fucoxanthin.

In another study performed in vitro using sarcoma 180 (S180), with Kunming mice, fucoxanthin was administered orally, in doses of 25, 50 and $100 \mathrm{mg} / \mathrm{kg}$, once daily for 1 week, revealing the ability to induce apoptosis tumor cells [98]. However, the authors attributed the ability to inhibit the expression of epidermal growth factor receptor (EGFR) and signal transducers and transcription activators (STATs) (important for tumor survival) as a possible antitumor effect and induction of apoptosis achieved by fucoxanthin.

Even a fucoxanthin metabolite, fucoxanthinol, has already been tested for its antitumor activity. Using NOD-SCID mice inoculated with colorectal cancer cells, Terasaki et al., 2017 [99] compared groups treated with fucoxanthinol (5 mg / kg body weight every 3-4 days) to control groups. The authors defined the tumor size and body weight as parameters for evaluation. The results showed that there was little difference in body weight between the two groups, but the tumor size of the fucoxanthinol group demonstrated significant suppression after a period of 10 days, thus confirming the action of this metabolite compared to the control group. The same assessment was carried out by Ishikawa et al., 2008 [100], using HUT-102 leukemic cells inoculated in SCID mice: over 4 weeks of treatment neither the fucoxanthinol nor the control group showed adverse effects on general appearance, body weight and food intake. After 14 days, the fucoxanthinol group showed significantly smaller tumors, and these weighed significantly less when excised than the control group. In addition, the level of the tumor marker sIL-2R $\alpha$ in serum was significantly lower, and the TUNEL assays revealed more tumor apoptotic cells in the fucoxanthinol-treated group.

\section{Conclusion}

Fucans, especially fucoidans, are heterogeneous and complex compounds, with the structures not yet fully elucidated. Due to the lack of standardization in the methodologies used for the isolation of their compounds, there is a lack of knowledge about the determination of the relationships between their structures and their activities. However, the compositions and structures found so far demonstrate important activities that may be more related to the originality of these structures than to a conventional performance found in other metabolites. Activation of the intrinsic and extrinsic pathways of apoptosis, modulation of the immune response, suppression of angiogenesis and reduced adhesion of tumor cells to human platelets are mechanisms that have been suggested as responsible for the significant antitumor activity of the compounds. Preclinical and clinical studies have already been reported in the literature; however, additional studies on the conformation of these structures and on their mechanism, efficacy and safety are desirable to improve the comprehension of their biological activities and for the development of new chemotherapeutics or chemopreventives, helping to innovate and improve cancer treatments. 


\section{Compliance with ethical standards}

\section{Acknowledgments}

The authors thank to Marisa Rangel for her collaboration and scientific advice.

\section{Disclosure of conflict of interest}

The authors declare no conflict of interest.

\section{References}

[1] Mayer AMS, Guerrero AJ, Rodríguez AD, Taglialatela-Scafati O, Nakamura F, Fusetani N. Marine Pharmacology in 2014-2015: Marine Compounds with Antibacterial, Antidiabetic, Antifungal, Anti-Inflammatory, Antiprotozoal, Antituberculosis, Antiviral, and Anthelmintic Activities; Affecting the Immune and Nervous Systems, and Other Miscellaneous . Mar Drugs. 2019; 18(1): 2-76.

[2] Molinski TF, Dalisay DS, Lievens SL, Saludes JP. Drug development from marine natural products. Nat Rev Drug Discov. 2009; 8(1): 69-85.

[3] Gupta S, Abu-Ghannam N. Bioactive potential and possible health effects of edible brown seaweeds. Trends Food Sci Technol. 2011; 22(6): 315-26.

[4] El-Said GF, El-Sikaily A. Chemical composition of some seaweed from Mediterranean Sea coast, Egypt. Environ Monit Assess. 2013; 185(7): 6089-99.

[5] Murphy C, Hotchkiss S, Worthington J, McKeown SR. The potential of seaweed as a source of drugs for use in cancer chemotherapy. J Appl Phycol. 2014; 26(5): 2211-64.

[6] Ohta Y, Lee JB, Hayashi K, Hayashi T. Isolation of sulfated galactan from codium fragile and its antiviral effect. Biol Pharm Bull. 2009; 32(5): 892-8.

[7] Rocha HAO, Franco CRC, Trindade ES, Carvalho LCM, Veiga SS, Leite EL, et al. A fucan from the brown seaweed Spatoglossum schröederi inhibits Chinese hamster ovary cell adhesion to several extracellular matrix proteins. Brazilian J Med Biol Res. 2001; 34(5): 621-6.

[8] Bilan MI, Usov AI. Structural analysis of fucoidans. Nat Prod Commun. 2008; 3(10): 1639-48.

[9] Jiao G, Yu G, Zhang J, Ewart HS. Chemical structures and bioactivities of sulfated polysaccharides from marine algae. Mar Drugs. 2011; 9(2): 196-233.

[10] Hyun J-H, Kim S-C, Kang J-I, Kim M-K, Boo H-J, Kwon J-M, et al. Apoptosis Inducing Activity of Fucoidan in HCT15 Colon Carcinoma Cells. Biol Pharm Bull. 2009; 32(10): 1760-4.

[11] Alves C, Silva J, Pinteus S, Gaspar H, Alpoim MC, Botana LM, et al. From Marine Origin to Therapeutics: The Antitumor Potential of Marine Algae-Derived Compounds. Front Pharmacol. 2018; 9: 1-24.

[12] Rocha DHA, Seca AML, Pinto DCGA. Seaweed secondary metabolites in vitro and in vitro anticancer activity. Mar Drugs. 2018; 16(11): 1-27.

[13] Oliveira MN de, Freitas ALP, Carvalho AFU, Sampaio TMT, Farias DF, Alves Teixeira DI, et al. Nutritive and nonnutritive attributes of washed-up seaweeds from the coast of Ceará, Brazil. Food Chem. 2009; 115(1): 254-9.

[14] Kilinç B, Cirik S, Turan G, Tekogul H, Koru E. Seaweeds for Food and Industrial Applications. In: Food Industry. InTech. 2013; 475-82.

[15] Khalifa SAM, Elias N, Farag MA, Chen L, Saeed A, Hegazy MEF, et al. Marine natural products: A source of novel anticancer drugs. Mar Drugs. 2019; 17(9): 1-31.

[16] Zorofchian Moghadamtousi S, Karimian H, Khanabdali R, Razavi M, Firoozinia M, Zandi K, et al. Anticancer and Antitumor Potential of Fucoidan and Fucoxanthin, Two Main Metabolites Isolated from Brown Algae. Sci World J. 2014; 1-10.

[17] Berteau 0, Mulloy B. Sulfated fucans, fresh perspectives: Structures, functions, and biological properties of sulfated fucans and an overview of enzymes active toward this class of polysaccharide. Glycobiology. 2003; 13(6): 29-40. 
[18] Kylin H. Zur Biochemie der Meeresalgen. Hoppe Seylers Z Physiol Chem. 1913; 83(3): 171-97.

[19] Li B, Lu F, Wei X, Zhao R. Fucoidan: Structure and bioactivity. Molecules. 2008; 13(8): 1671-95.

[20] Rocha Amorim MO, Lopes Gomes D, Dantas LA, Silva Viana RL, Chiquetti SC, Almeida-Lima J, et al. Fucan-coated silver nanoparticles synthesized by a green method induce human renal adenocarcinoma cell death. Int J Biol Macromol. 2016; 93: 57-65.

[21] Fernandes-Negreiros MM, Araújo Machado RI, Bezerra FL, Nunes Melo MC, Alves MGCF, Alves Filgueira LG, et al. Antibacterial, antiproliferative, and immunomodulatory activity of silver nanoparticles synthesized with fucans from the alga dictyota mertensii. Nanomaterials. 2018; 8(1): 1-15.

[22] Mak W, Hamid N, Liu T, Lu J, White WL. Fucoidan from New Zealand Undaria pinnatifida: Monthly variations and determination of antioxidant activities. Carbohydr Polym. 2013; 95(1): 606-14.

[23] Fletcher HR, Biller P, Ross AB, Adams JMM. The seasonal variation of fucoidan within three species of brown macroalgae. Algal Res. 2017; 22: 79-86.

[24] Magalhaes KD, Costa LS, Fidelis GP, Oliveira RM, Nobre LTDB, Dantas-Santos N, et al. Anticoagulant, antioxidant and antitumor activities of heterofucans from the seaweed dictyopteris delicatula. Int J Mol Sci. 2011; 12(5): 3352-65.

[25] Ermakova S, Sokolova R, Kim SM, Um BH, Isakov V, Zvyagintseva T. Fucoidans from brown seaweeds sargassum hornery, eclonia cava, costaria costata: Structural characteristics and anticancer activity. Appl Biochem Biotechnol. 2011; 164(6): 841-50.

[26] Mhadhebi L, Mhadhebi A, Robert J, Bouraoui A. Antioxidant, anti-inflammatory and antiproliferative effects of aqueous extracts of three mediterranean brown seaweeds of the Genus Cystoseira. Iran J Pharm Res. 2014; 13(1): 207-20.

[27] Teruya T, Konishi T, Uechi S, Tamaki H, Tako M. Anti-proliferative activity of oversulfated fucoidan from commercially cultured Cladosiphon okamuranus TOKIDA in U937 cells. Int J Biol Macromol. 2007; 41(3): 221-6.

[28] Dias PF, Siqueira JM, Vendruscolo LF, Neiva TDJ, Gagliardi AR, Maraschin M, et al. Antiangiogenic and antitumoral properties of a polysaccharide isolated from the seaweed Sargassum stenophyllum. Cancer Chemother Pharmacol. 2005; 56(4): 436-46.

[29] Costa LS, Fidelis GP, Telles CBS, Dantas-Santos N, Camara RBG, Cordeiro SL, et al. Antioxidant and antiproliferative activities of heterofucans from the seaweed Sargassum filipendula. Mar Drugs. 2011; 9(6): 95266.

[30] Ale MT, Mikkelsen JD, Meyer AS. Important determinants for fucoidan bioactivity: A critical review of structurefunction relations and extraction methods for fucose-containing sulfated polysaccharides from brown seaweeds. Mar Drugs. 2011; 9(10): 2106-30.

[31] Qiu X, Amarasekara A, Doctor V. Effect of oversulfation on the chemical and biological properties of fucoidan. Carbohydr Polym. 2006; 63(2): 224-8.

[32] Cho ML, Lee B-Y, You SG. Relationship between Oversulfation and Conformation of Low and High Molecular Weight Fucoidans and Evaluation of Their in vitro Anticancer Activity. Molecules. 2010; 16(1): 291-7.

[33] Haroun-Bouhedja F, Ellouali M, Sinquin C, Boisson-Vidal C. Relationship between sulfate groups and biological activities of fucans. Thromb Res. 2000; 100(5): 453-9.

[34] Yang L, Wang P, Wang H, Li Q, Teng H, Liu Z, et al. Fucoidan derived from Undaria pinnatifida induces apoptosis in human hepatocellular carcinoma SMMC-7721 cells via the ROS-mediated mitochondrial pathway. Mar Drugs. 2013; 11(6): 1961-76.

[35] Nardella A, Chaubet F, Boisson-Vidal C, Blondin C, Durand P, Jozefonvicz J. Anticoagulant low molecular weight fucans produced by radical process and ion exchange chromatography of high molecular weight fucans extracted from the brown seaweed Ascophyllum nodosum. Carbohydr Res. 1996; 289: 201-8.

[36] Yang C, Chung D, Shin IS, Lee HY, Kim JC, Lee YJ, et al. Effects of molecular weight and hydrolysis conditions on anticancer activity of fucoidans from sporophyll of Undaria pinnatifida. Int J Biol Macromol. 2008; 43(5): 433-7.

[37] Kimura R, Rokkaku T, Takeda S, Senba M, Mori N. Cytotoxic effects of fucoidan nanoparticles against osteosarcoma. Mar Drugs. 2013; 11(11): 4267-78. 
[38] Haneji K, Matsuda T, Tomita M, Kawakami H, Ohshiro K, Uchihara JN, et al. Fucoidan extracted from Cladosiphon Okamuranus Tokida induces apoptosis of human T-cell leukemia virus type 1-infected T-cell lines and primary adult T-cell leukemia cells. Nutr Cancer. 2005; 52(2): 189-201.

[39] Black WAP, Dewar ET, Woodward FN. Manufacture of algal chemicals. IV - Laboratory-scale isolation of fucoidin from brown marine algae. J Sci Food Agric. 1952; 3(3): 122-9.

[40] Costa LS, Fidelis GP, Cordeiro SL, Oliveira RM, Sabry DA, Câmara RBG, et al. Biological activities of sulfated polysaccharides from tropical seaweeds. Biomed Pharmacother. 2010; 64: 21-8.

[41] Kusaykin MI, Chizhov AO, Grachev AA, Alekseeva SA, Bakunina IY, Nedashkovskaya OI, et al. A comparative study of specificity of fucoidanases from marine microorganisms and invertebrates. J Appl Phycol. 2006; 18(3-5): 36973.

[42] Zvyagintseva TN, Shevchenko NM, Nazarenko EL, Gorbach VI, Urvantseva AM, Kiseleva MI, et al. Water-soluble polysaccharides of some brown algae of the Russian Far-East. Structure and biological action of low-molecular mass polyuronans. J Exp Mar Bio Ecol. 2005; 320(2): 123-31.

[43] Marais MF, Joseleau JP. A fucoidan fraction from Ascophyllum nodosum. Carbohydr Res. 2001; 336(2): 155-9.

[44] Colliec S, Boisson-vidal C, Jozefonvicz J. A low molecular weight fucoidan fraction from the brown seaweed Pelvetia canaliculata. Phytochemistry. 1994; 35(3): 697-700.

[45] Conchie J, Percival EG V. Fucoidin. Part II. The hydrolysis of a methylated fucoidin prepared from Fucus vesiculosus. J Chem Soc. 1950; 827-32.

[46] Percival EG V., Ross AG. Fucoidin. Part I. The isolation and purification of fucoidin from brown seaweeds. J Chem Soc. 1950; (0): 717-20.

[47] O’Neill AN. Degradative Studies on Fucoidin. J Am Chem Soc. 1954; 76(20): 5074-6.

[48] Patankar MS, Oehninger S, Barnett T, Williams RL, Clark GF. A revised structure for fucoidan may explain some of its biological activities. J Biol Chem. 1993; 268(29): 21770-6.

[49] Pereira MS, Mulloy B, Mourão PAS. Structure and anticoagulant activity of sulfated fucans. Comparison between the regular, repetitive, and linear fucans from echinoderms with the more heterogeneous and branched polymers from brown algae. J Biol Chem. 1999; 274(12): 7656-67.

[50] Ponce NMA, Pujol CA, Damonte EB, Flores ML, Stortz CA. Fucoidans from the brown seaweed Adenocystis utricularis: Extraction methods, antiviral activity and structural studies. Carbohydr Res. 2003; 338(2): $153-65$.

[51] Koh HSA, Lu J, Zhou W. Structure characterization and antioxidant activity of fucoidan isolated from Undaria pinnatifida grown in New Zealand. Carbohydr Polym. 2019; 212: 178-85.

[52] Mian AJ, Percival E. Carbohydrates of the brown seaweeds himanthalia lorea, bifurcaria bifurcata, and Padina pavonia. Part I. extraction and fractionation. Carbohydr Res. 1973; 26(1): 133-46.

[53] Chevolot L, Mulloy B, Ratiskol J, Foucault A, Colliec-Jouault S. A disaccharide repeat unit is the major structure in fucoidans from two species of brown algae. Carbohydr Res. 2001; 330(4): 529-35.

[54] Duarte ME., Cardoso MA, Noseda MD, Cerezo AS. Structural studies on fucoidans from the brown seaweed Sargassum stenophyllum. Carbohydr Res. 2001; 333(4): 281-93.

[55] Nagaoka M, Shibata H, Kimura-Takagi I, Hashimoto S, Kimura K, Makino T, et al. Structural study of fucoidan from Cladosiphon okamuranus TOKIDA. Glycoconj J. 1999; 16(1): 19-26.

[56] Fraser PD, Bramley PM. The biosynthesis and nutritional uses of carotenoids. Prog Lipid Res. 2004; 43(3): 22865.

[57] Oliver J, Palou A. Chromatographic determination of carotenoids in foods. J Chromatogr A. 2000; 881(1-2): 54355.

[58] Willstätter R, Page HJ. Untersuchungen über Chlorophyll. XXIV. Über die Pigmente der Braunalgen. Justus Liebig's Ann der Chemie. 1914; 404(3): 237-71.

[59] Dembitsky VM, Maoka T. Allenic and cumulenic lipids. Prog Lipid Res. 2007; 46(6): 328-75.

[60] Hosokawa M, Kudo M, Maeda H, Kohno H, Tanaka T, Miyashita K. Fucoxanthin induces apoptosis and enhances the antiproliferative effect of the PPAR $\gamma$ ligand, troglitazone, on colon cancer cells. Biochim Biophys Acta - Gen Subj. 2004; 1675(1-3): 113-9. 
[61] Englert G, Bjørnland T, Liaaen-Jensen S. 1D and 2D NMR study of some allenic carotenoids of the fucoxanthin series. Magn Reson Chem. 1990; 28(6): 519-28.

[62] Das SK, Hashimoto T, Shimizu K, Yoshida T, Sakai T, Sowa Y, et al. Fucoxanthin induces cell cycle arrest at G0/G1 phase in human colon carcinoma cells through up-regulation of p21WAF1/Cip1. Biochim Biophys Acta - Gen Subj. 2005; $1726(3): 328-35$.

[63] Sachindra NM, Sato E, Maeda H, Hosokawa M, Niwano Y, Kohno M, et al. Radical scavenging and singlet oxygen quenching activity of marine carotenoid fucoxanthin and its metabolites. J Agric Food Chem. 2007; 55(21): 851622 .

[64] Miyashita K, Hosokawa M. Fucoxanthin in the management of obesity and its related disorders. J Funct Foods. 2017; 36: 195-202.

[65] Maeda H, Hosokawa M, Sashima T, Funayama K, Miyashita K. Fucoxanthin from edible seaweed, Undaria pinnatifida, shows antiobesity effect through UCP1 expression in white adipose tissues. Biochem Biophys Res Commun. 2005; 332(2): 392-7.

[66] Su J, Guo K, Huang M, Liu Y, Zhang J, Sun L, et al. Fucoxanthin, a marine xanthophyll isolated from Conticribra weissflogii ND-8: Preventive anti-inflammatory effect in a mouse model of sepsis. Front Pharmacol. 2019; 10: 117.

[67] Hu L, Chen W, Tian F, Yuan C, Wang H, Yue H. Neuroprotective role of fucoxanthin against cerebral ischemic/reperfusion injury through activation of Nrf2/HO-1 signaling. Biomed Pharmacother. 2018; 106(1): 1484-9.

[68] Wang Z, Li H, Dong M, Zhu P, Cai Y. The anticancer effects and mechanisms of fucoxanthin combined with other drugs. J Cancer Res Clin Oncol. 2019; 145(2): 293-301.

[69] Pádua D, Rocha E, Gargiulo D, Ramos AA. Bioactive compounds from brown seaweeds: Phloroglucinol, fucoxanthin and fucoidan as promising therapeutic agents against breast cancer. Phytochem Lett. 2015; 14: 918.

[70] Kwak JY. Fucoidan as a marine anticancer agent in preclinical development. Mar Drugs. 2014; 12(2): 851-70.

[71] Kim EJ, Park SY, Lee JY, Park JHY. Fucoidan present in brown algae induces apoptosis of human colon cancer cells. BMC Gastroenterol. 2010; 10: 1-11.

[72] Aisa Y, Miyakawa Y, Nakazato T, Shibata H, Saito K, Ikeda Y, et al. Fucoidan induces apoptosis of human HS-Sultan cells accompanied by activation of caspase-3 and down-regulation of ERK pathways. Am J Hematol. 2005; 78(1): 7-14.

[73] Banafa AM, Roshan S, Liu YY, Chen HJ, Chen MJ, Yang GX, et al. Fucoidan induces G1 phase arrest and apoptosis through caspases-dependent pathway and ROS induction in human breast cancer MCF-7 cells. J Huazhong Univ Sci Technol - Med Sci. 2013; 33(5): 717-24.

[74] Koyanagi S, Tanigawa N, Nakagawa H, Soeda S, Shimeno H. Oversulfation of fucoidan enhances its anti-angiogenic and antitumor activities. Biochem Pharmacol. 2003; 65(2): 173-9.

[75] Jin JO, Song MG, Kim YN, Park JI, Kwak JY. The mechanism of fucoidan-induced apoptosis in leukemic cells: Involvement of ERK1/2, JNK, glutathione, and nitric oxide. Mol Carcinog. 2010; 49(8): 771-82.

[76] Boo HJ, Hyun JH, Kim SC, Kang J Il, Kim MK, Kim SY, et al. Fucoidan from Undaria pinnatifida induces apoptosis in A549 human lung carcinoma cells. Phyther Res. 2011; 25(7): 1082-6.

[77] Boo HJ, Hong JY, Kim SC, Kang J Il, Kim MK, Kim EJ, et al. The anticancer effect of fucoidan in PC-3 prostate cancer cells. Mar Drugs. 2013; 11(8): 2982-99.

[78] Yamasaki-Miyamoto Y, Yamasaki M, Tachibana H, Yamada K. Fucoidan induces apoptosis through activation of caspase-8 on human breast cancer MCF-7 cells. J Agric Food Chem. 2009; 57(18): 8677-82.

[79] Fukahori S, Yano H, Akiba J, Ogasawara S, Momosaki S, Sanada S, et al. Fucoidan, a major component of brown seaweed, prohibits the growth of human cancer cell lines in vitro. Mol Med Rep. 2008; 1(4): 537-42.

[80] Moreau D, Thomas-Guyon H, Jacquot C, Jugé M, Culioli G, Ortalo-Magné A, et al. An extract from the brown alga Bifurcaria bifurcata induces irreversible arrest of cell proliferation in a non-small-cell bronchopulmonary carcinoma line. J Appl Phycol. 2006; 18(1): 87-93. 
[81] Zhang Z, Teruya K, Eto H, Shirahata S. Fucoidan extract induces apoptosis in MCF-7 cells via a mechanism involving the ros-dependent JNK activation and mitochondria-mediated pathways. PLoS One. 2011; 6(11): 1-14.

[82] Abu-Khudir R, Ismail GA, Diab T. Antimicrobial, Antioxidant, and Anti-Tumor Activities of Sargassum linearifolium and Cystoseira crinita from Egyptian Mediterranean Coast. Nutr Cancer. 2020; 73(5): 829-44.

[83] Kang KA, Kim JK, Jeong YJ, Na S-Y, Hyun JW. Dictyopteris undulata Extract Induces Apoptosis via Induction of Endoplasmic Reticulum Stress in Human Colon Cancer Cells. J Cancer Prev. 2014; 19(2): 118-24.

[84] Olivares-Bañuelos T, Gutiérrez-Rodríguez AG, Méndez-Bellido R, Tovar-Miranda R, Arroyo-Helguera 0, JuárezPortilla C, et al. Brown Seaweed Egregia menziesii's Cytotoxic Activity against Brain Cancer Cell Lines. Molecules. 2019;24(2):1-14.

[85] Philchenkov A, Zavelevich M, Imbs T, Zvyagintseva T, Zaporozhets T. Sensitization of human malignant lymphoid cells to etoposide by fucoidan, a brown seaweed polysaccharide. Exp Oncol. 2007;29(3):181-5.

[86] Thinh PD, Menshova R V., Ermakova SP, Anastyuk SD, Ly BM, Zvyagintseva TN. Structural characteristics and anticancer activity of fucoidan from the brown alga Sargassum mcclurei. Mar Drugs. 2013; 11(5): 1453-76.

[87] Karim H, Ahmad A, Natzir R, Massi MN, Arfah R, Asmi N, et al. Isolation and identification of bioactive proteins from the brown algae Sargassum, Sp. and their potential as anticancer agents. J Phys Conf Ser. 2019; 1341(3): 19.

[88] Xue M, Ge Y, Zhang J, Wang Q, Hou L, Liu Y, et al. Anticancer properties and mechanisms of fucoidan on mouse breast cancer in vitro and in vitro. PLoS One. 2012; 7(8): 3-11.

[89] Reyes ME, Riquelme I, Salvo T, Zanella L, Letelier P, Brebi P. Brown Seaweed Fucoidan in Cancer: Implications in Metastasis and Drug Resistance. Mar Drugs. 2020; 18(5): 2-18.

[90] Ale MT, Maruyama H, Tamauchi H, Mikkelsen JD, Meyer AS. Fucoidan from Sargassum sp. and Fucus vesiculosus reduces cell viability of lung carcinoma and melanoma cells in vitro and activates natural killer cells in mice in vitro. Int J Biol Macromol. 2011; 49(3): 331-6.

[91] He X, Xue M, Jiang S, Li W, Yu J, Xiang S. Fucoidan promotes apoptosis and inhibits EMT of breast cancer cells. Biol Pharm Bull. 2019; 42(3): 442-7.

[92] Maruyama H, Tamauchi H, Iizuka M, Nakano T. The role of NK cells in antitumor activity of dietary fucoidan from Undaria pinnatifida sporophylls (Mekabu). Planta Med. 2006; 72(15): 1415-7.

[93] Tocaciu S, Oliver LJ, Lowenthal RM, Peterson GM, Patel R, Shastri M, et al. The Effect of Undaria pinnatifida Fucoidan on the Pharmacokinetics of Letrozole and Tamoxifen in Patients With Breast Cancer. Integr Cancer Ther. 2018; 17(1): 99-105.

[94] Azuma K, Ishihara T, Nakamoto H, Amaha T, Osaki T, Tsuka T, et al. Effects of oral administration of fucoidan extracted from Cladosiphon okamuranus on tumor growth and survival time in a tumor-bearing mouse model. Mar Drugs. 2012; 10(10): 2337-48.

[95] Ikeguchi M, Yamamoto M, Arai Y, Maeta Y, Ashida K, Katano K, et al. Fucoidan reduces the toxicities of chemotherapy for patients with unresectable advanced or recurrent colorectal cancer. Oncol Lett. 2011; 2(2): 319-22.

[96] Martin LJ. Fucoxanthin and its metabolite fucoxanthinol in cancer prevention and treatment. Mar Drugs. 2015; 13(8): 4784-98.

[97] Okuzumi J, Takahashi T, Yamane T, Kitao Y, Inagake M, Ohya K, et al. Inhibitory effects of fucoxanthin, a natural carotenoid, on N-ethyl-N'-nitro-N-nitrosoguanidine-induced mouse duodenal carcinogenesis. Cancer Lett. 1993; 68(2-3): 159-68.

[98] Wang J, Chen S, Xu S, Yu X, Ma D, Hu X, et al. In vitro induction of apoptosis by fucoxanthin, a marine carotenoid, associated with down-regulating STAT3/EGFR signaling in sarcoma 180 (S180) xenografts-bearing mice. Mar Drugs. 2012; 10(9): 2055-68.

[99] Terasaki M, Maeda H, Miyashita K, Tanaka T, Miyamoto S, Mutoh M. A marine bio-functional lipid, fucoxanthinol, attenuates human colorectal cancer stem-like cell tumorigenicity and sphere formation. J Clin Biochem Nutr. 2017; 61(1): 25-32.

[100] Ishikawa C, Tafuku S, Kadekaru T, Sawada S, Tomita M, Okudaira T, et al. Antiadult T-cell leukemia effects of brown algae fucoxanthin and its deacetylated product, fucoxanthinol. Int J Cancer. 2008; 123(11): $2702-12$. 